\title{
Employment and wage behaviour of industrial enterprises in transition economies: The cases of Poland and Czechoslovakia $^{1}$
}

\section{Swati Basu*, Saul Estrin** and Jan Svejnar ${ }^{2}$}

*University of Pittsburgh

4M30 Forbes Quadrangle

Pittsburgh

PA 15260

\author{
**London Business School \\ Sussex Place, Regent's Park \\ London NW1 4SA \\ Tel: $+44(0) 1712625050 \mathrm{Xtn} 3463$ \\ Fax: +44(0)171 4020718 \\ E-mail: sestrin@lbs.ac.uk
}

\begin{abstract}
In this paper we use two very large panel datasets from Poland, 1988-90 and Czechoslovakia, 1990-1992 to explore the dynamics of employment and wage determination at the enterprise level in the early years of transition. The study is intended to assist in building a coherent picture of microeconomic adjustment in transition, a field which was not sufficiently explored in the early years of reform. We find that Polish firms were already to some extent responsive to market conditions pre-reform, notably to demand in determining employment. Czechoslovak firms, however, were largely unresponsive to such pressures in 1989-90. The elasticities rose significantly in both countries in the early years of reform, especially in Czechoslovakia which quickly attained initial Polish patterns of adjustment. Firms became much more responsive to sales and cost pressures in adjusting employment and to their own productivity in setting pay. Ownership effects in these early years were, however, much more modest, with state-owned firms adjusting employment more than their private counterparts, perhaps because over-manning was more serious in that sector.
\end{abstract}

JEL classification: J23, J30, P11.

Keywords: employment, wages, transition.

\section{Introduction}

The economies of Central and Eastern Europe are well advanced in their dramatic transition from a centrally planned to a market-oriented system. Cross-country comparisons indicate that in terms of many variables, the transition experience has been 
diverse. Some countries, such as the Czech Republic (see Svejnar, 1995), Russia (see Boycko, Shleifer and Vishny, 1995) and former East Germany (see Carlin, 1994) have, for instance, succeeded in carrying out a massive privatization of state property. Others, such as Bulgaria, Hungary, Poland and Romania have been much slower in privatizing their state sectors (see, e.g., Estrin, 1994). Some, such as the Czech Republic, have followed the orthodox model of first stabilizing at the macro level and then restructuring at the level of sectors, industries and firms. Others have also shown that it is possible to reorient exports, create new firms, and commercialize existing firms amidst macroeconomic instability (see, e.g., Estrin, Gelb and Singh, 1995).

There are some patterns, however, which have clearly emerged from the official statistics for the first two or three years of transition and which deserve systematic analysis. First, aggregate output fell dramatically in all the economies in the first phase of transition, with the fall exceeding 20 per cent in most countries ${ }^{3}$ (see, e.g., World Bank Development Report, 1996). Second, employment also fell in those early years, although its decline was less pronounced and somewhat lagging behind the decrease in output. Third, real wages fell dramatically in the first two years of transition as the countries devalued their currencies, freed most prices and imposed wage (bill) controls. With the exception of the Czech and Slovak Republics, where producer and consumer price indices moved more or less in tandem (see Dyba and Svejnar, 1995), the decline in real producer wages was much less pronounced than the decline in real consumer wages. ${ }^{4}$ The fourth important feature, for which the experience of all the countries except for the Czech Republic and former Soviet Union is identical, is the rapidly rising and

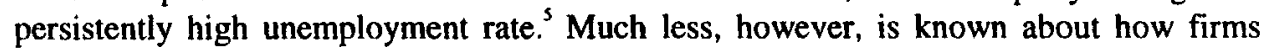
have adjusted to the enormous changes in their structures, macroenvironment and operating conditions and the factors influencing their responsiveness to changes in policy parameters.

This has made analysts and policy-makers switch from an almost exclusive focus on macro-stabilization issues in the early phase of transition to a more balanced view of the relative importance of macro and micro developments. For example, evaluations such as those of the EBRD Transition Report and the World Bank Development Report have begun to place increasing emphasis on institutional legal and microeconomic change. Indeed, there is growing consensus that understanding the behaviour of enterprises and their responses to policy measures may be crucial for a successful transition. In this paper, we seek to contribute to this movement by using large, enterprise-level panel datasets from the Czech Republic, Slovakia, and Poland to provide a systematic analysis of the employment and wage-setting behaviour at the enterprise level for various types of firms during the different stages of early transition. Our empirical framework is outlined in the following section, and the empirical work is reported in the third. Conclusions are drawn in the final section.

\section{The analytical framework}

The paper seeks to provide micro-econometric evidence on the adjustment of enterprise wages and employment at different stages of transition in Poland, the Czech Republic and Slovakia. We use annual enterprise-level data from 1988 to 1992 to estimate augmented employment and wage equations, from which we calculate estimates of labour demand and wage elasticities to be contrasted across countries and years.

In estimating the employment equation, we use the following general specification:

$$
L=L(W, Q, X)
$$


where $L=$ number of employees, $W=$ the real producer wage (nominal wage deflated by the producer price index), $Q=$ the real sales of the firm (nominal sales deflated by the producer price index), and $X=a$ vector of structural and policy variables that may affect the firm's demand for labour. The specification in Equation (1) corresponds to a labour demand function of an enterprise characterized by cost minimization subject to an exogenously given level of output (see, e.g., Hamermesh, 1986). This approach has been used fruitfully in the West (Hamermesh, 1986) and it appears appropriate in the present context in that the negative sales shock brought about by the dissolution of the CMEA, the collapse of the Soviet market, and the restrictive macroeconomic policies probably imposed an exogenous sales constraint on firms in Central and Eastern Europe. Nevertheless, the sampled firms may not have been entirely sales constrained and despite wage (bill) controls in the countries in question, wages may not have been set exogenously outside the firm. As a result, in addition to using ordinary least squares (OLS), we also estimate Equation (1) with $W$ and $Q$ instrumented by exogenous and predetermined variables.

The hypothesis that, in addition to exogenous factors, wages may depend on enterprise characteristics leads us to estimate a wage regression of the form:

$$
W=W(Q / L, Z)
$$

where $Q / L=$ sales per employee and $Z=$ a vector of relevant structural and policy variables that may affect wages in a given firm. Sales per employee is included as an indicator of rents potentially available for distribution within the firm, and therefore as a firm-specific proxy for ability to pay. Sales per employee may however be endogenous and we instrument $Q / L$ in our estimates of Equation (2) by exogenous and predetermined variables.

The period of analysis covers several years but our interest is in behavioural change which is best viewed via year-to-year variation. However, adjustment by firms is not likely to be instantaneous so we allow for dynamics in estimating both Equations (1) and (2) (see, e.g., Nickell, 1986). We specify the two equations in loglinear form and introduce a partial adjustment framework by including the lagged dependent variable on the right-hand side, as well as a more general dynamic framework by allowing all the principal right-hand side variables to enter in both current and lagged form (see, e.g., Hendry and Mizon, 1978 and Estrin and Svejnar, 1993). Formally, Equation (1) is then:

$$
\begin{aligned}
\ln L_{t}=\alpha_{o}+\alpha_{l} \ln (W)_{t} & +\alpha_{2} \ln (W)_{t-1}+\alpha_{3} \ln Q_{t}+\alpha_{4} \ln Q_{t-1} \alpha_{5} \ln X_{t} \\
& +\alpha_{6} \ln X_{t-1}+\alpha_{7} \ln L_{t-1}
\end{aligned}
$$

Note that, within Equation (1'), one can conveniently test if (a) a partial adjustment model is the appropriate specification $\alpha_{2}=\alpha_{4}=\alpha_{6}=0$, (b) a completely static model is supported by the data and $\alpha_{2}=\alpha_{4}=\alpha_{6}=\alpha_{7}=0$, (c) a fixed effects model is the preferred specification $\alpha_{2}=\alpha_{1}, \alpha_{4}=\alpha_{3}, \alpha_{6}=\alpha_{5}$, and $\alpha_{7}=1$. The model in Equation (1') therefore nests a variety of plausible specifications. The dynamic wage equation is specified analogously to the employment Equation (1'), and parallel tests can be applied.

\section{Data and empirical findings}

Summary statistics on firm-level and more aggregate variables used in the analysis are given in Tables 1 and 2. Table 1 presents the means and standard deviations of annual 
Czechoslovak data for 1990-92. Table 2 contains data for Polish firms during the 198890 period. These data cover the majority of Czechoslovak and Polish industrial firms. They provide production, employment and wage statistics, as well as information on some other variables. However, they are relatively uninformative about many aspects of enterprise performance. As a result, we have also analysed data from a special survey of 200 Polish industrial enterprises undertaken in 1993-94 as part of the World Bank project on Enterprise Performance in Transition. The 200 firm sample is a structured random sample, selected to contain 60 per cent state-owned firms, 20 per cent privatized firms, and 20 per cent de novo formed private companies (see Belka et. al., (1994) for a detailed discussion of the sample).

Table 1. Means (standard deviations) of principal variables for Czechoslovakia, 1990-92

\begin{tabular}{lccc}
\hline & 1990 & 1991 & 1992 \\
\hline Average monthly wage (Kcs) & 3,249 & 3,757 & 4,357 \\
& $(394)$ & $(608)$ & $(971)$ \\
Consumer price index (\%) & 10.4 & 61.2 & 10.1 \\
Producer price index (\%) & 4.8 & 68.9 & 5.3 \\
Sales (million Kcs) & 208.59 & 213.95 & 445.94 \\
No. of employees & $(588.9)$ & $(936.89)$ & $(2,118.70)$ \\
& 1,832 & 1,257 & 700 \\
& $(3,939)$ & $(2,931)$ & $(1,911)$ \\
\hline
\end{tabular}

Table 2. Means (standard deviations) of principal variables for Poland, 1988-90

\begin{tabular}{lccc}
\hline & $\mathbf{1 9 8 8}$ & 1989 & 1990 \\
\hline Average annual wage $(\mathbf{1 , 0 0 0 ~ Z I )}$ & 608.93 & $2,291.09$ & $10,460.34$ \\
& $(164.33)$ & $(604.17)$ & $(3,357.45)$ \\
Consumer price index & 100.00 & 351.08 & 2.407 .58 \\
$(\mathbf{1 9 8 8}=\mathbf{1 0 0 )}$ & $(0)$ & $(0)$ & $(0)$ \\
Producer price index & 100.00 & 321.60 & $2,054.14$ \\
$\mathbf{( 1 9 8 8 = 1 0 0 )}$ & $(5.01)$ & $(38.63)$ & $(419.0)$ \\
No. of employees & $\mathbf{7 2 6 . 4 5}$ & $\mathbf{6 9 4 . 3 0}$ & 701.65 \\
& $(1,315.31)$ & $(1,271.05)$ & $(1,293.23)$ \\
Sales (million Zl) & $5,838.56$ & $18,509.41$ & $100,458.78$ \\
& $(19,719.14)$ & $(57,003.68)$ & $(39,866.04)$ \\
\hline
\end{tabular}

In examining the nominal monthly wages and price indices in Table 1 , one observes the well documented phenomenon of real wages falling dramatically in Czechoslovakia in 1991 and gaining some ground in 1992. One can also see clearly the less well documented rising dispersion in inter-enterprise earnings during the transition, with the standard deviation starting at $394 \mathrm{Kcs}$ in 1990 and reaching $971 \mathrm{Kcs}$ in 1992. With the average wage rising from 3,249 crowns in 1990 to $4,357 \mathrm{Kcs}$ in 1992 , the coefficient of 
variation increased from 12 per cent to 22 per cent in this period.

The average number of employees per firm decreased steadily from 1,832 to 700 during the 1990-92 period, reflecting significant reductions of the labour force in many firms, the major wave of breakups and spin-offs of firms, ${ }^{8}$ and the entry of many smaller firms. One also observes a major real decrease in sales between 1990 and 1991 as transition started and firms became temporarily demand constrained. There was a significant increase in average sales between 1991 and 1992 as firms unloaded accumulated inventories.

The Polish data in Table 2 tell a different story, with average employment per firm hovering around 700 throughout the $1988-90$ period. The difference between the Czechoslovak and Polish data is in part accounted for by the fact that Poland did not create the same giant enterprises as did Czechoslovakia and Hungary in the 1980 s, as well as by the fact that the Polish dataset does not include small private firms."

\subsection{Employment}

Estimated coefficients of the employment equation are presented in Tables 3-5. Table 3 contains estimates for the recorded population of Czechoslovak industrial firms during the 1989-92 period. Estimates in Table 4 relate to the recorded population of Polish industrial firms between 1988 and 1990. Table 5 presents results based on data from 161-163 Polish firms that were sampled as part of the 200 firm survey in 1992-93. The datasets hence enable us to provide a relatively uninterrupted chronicle of the employment behaviour of Czechoslovak firms before and during the transition, as well as a somewhat more synthetic chronology of the developments in Polish industry.

Since transition is a dynamic process, which strives to change fundamentally the functioning of an economy, our approach is to estimate the dynamic model given by Equation (1') on short (two-year), consecutive panels of data. This approach enables us to take advantage of the panel nature of the data, leads to a minimal loss of data brought about by enterprise breakups, and permits us to identify structural (coefficient) changes over the different phases of transition. For the Czechoslovak data we hence present in Table 3 estimates for the pre-transition period of 1989-90, the early transition period of 1990-91, and the somewhat more mature (1991-92) phase of transition. For Poland, we present in Table 4 results for the pre-transition period of 1988-89 and the early transition period of 1989-90. Estimates for the more mature phase of Polish transition are reported for the smaller sample of firms in Table 5. The estimates in Tables 3 and 4 are instrumental variable (IV) estimates, and those in Table 5 use OLS. ${ }^{10}$ The instrumental variables used in the larger datasets to obtain predicted values of sales and wages are ownership, industry and district (regional) dummy variables. In all regressions the fully fledged dynamic model with lagged endogenous variables proved to dominate statistically the more restricted (nested) versions. Nevertheless, we also present some of the more restricted estimates for the sake of comparison and for a better understanding of the transition process.

\subsubsection{The Czechoslovak estimates}

The 1989-92 Czechoslovak estimates in Table 3 indicate that firms' employmentsetting behaviour at the start of the transition was characterized by significant inertia, as the 1989-90 estimated coefficient on lagged employment (0.975) was close to unity. The persistence decreased somewhat as transition unfolded in 199192 , although the coefficient remained above 0.9 . 
Table 3. IV estimates of employment equation for Czechoslovak firms, 1989-92

(Dependent variable is the logarithm of the number of employees, $\ln L_{t ;}$ values in parentheses are standard errors)

\begin{tabular}{|c|c|c|c|c|c|c|}
\hline & \multicolumn{2}{|c|}{$1989-90$} & \multicolumn{2}{|c|}{ 1990-91 } & \multicolumn{2}{|c|}{ 1991-92 } \\
\hline & (1) & (2) & (1) & (2) & (1) & $(2)$ \\
\hline $\ln \mathrm{L}_{1.1}$ & $\begin{array}{l}0.975^{*} \\
(0.008)\end{array}$ & & $\begin{array}{l}0.936 * \\
(0.016)\end{array}$ & & $\begin{array}{l}0.921^{*} \\
(0.017)\end{array}$ & \\
\hline $\ln Q_{1}$ & $\begin{array}{l}0.099^{*} \\
(0.015)\end{array}$ & $\begin{array}{l}0.897^{*} \\
(0.027)\end{array}$ & $\begin{array}{l}0.065^{*} \\
(0.014)\end{array}$ & $\begin{array}{l}0.777^{*} \\
(0.022)\end{array}$ & $\begin{array}{l}0.354^{*} \\
(0.034)\end{array}$ & $\begin{array}{l}0.666^{*} \\
(0.024)\end{array}$ \\
\hline $\ln Q_{t-1}$ & $\begin{array}{l}-0.078^{*} \\
(0.014)\end{array}$ & & $\begin{array}{r}-0.010 \\
(0.015)\end{array}$ & & $\begin{array}{l}-0.298 \\
(0.036)\end{array}$ & \\
\hline $\ln W_{1}$ & $\begin{array}{c}-0.277^{*} \\
(0.083)\end{array}$ & $\begin{array}{r}-1.752^{*} \\
(0.283)\end{array}$ & $\begin{array}{c}0.253^{* *} \\
(0.101)\end{array}$ & $\begin{array}{c}-2.203^{*} \\
(0.206)\end{array}$ & $\begin{array}{c}-0.191 * * \\
(0.095)\end{array}$ & $\begin{array}{r}-1.040^{*} \\
(0.173)\end{array}$ \\
\hline $\ln \mathbf{W}_{1-1}$ & $\begin{array}{l}0.219 * * \\
(0.083)\end{array}$ & & $\begin{array}{l}-0.148 \\
(0.101)\end{array}$ & & $\begin{array}{l}0.217^{* *} \\
(0.097)\end{array}$ & \\
\hline \multicolumn{7}{|l|}{ Ownership: } \\
\hline Private & & & $\begin{array}{l}-0.092 \\
(0.063)\end{array}$ & $\begin{array}{l}-0.073 \\
(0.285)\end{array}$ & $\begin{array}{l}-0.065 \\
(0.052)\end{array}$ & $\begin{array}{c}0.277^{* * *} \\
(0.144)\end{array}$ \\
\hline Co-operative & & & $\begin{array}{c}0.344 \\
(0.144)\end{array}$ & $\begin{array}{c}0.902 \\
(0.660)\end{array}$ & $\begin{array}{l}-0.173 \\
(0.156)\end{array}$ & $\begin{array}{l}0.055 \\
(0.434)\end{array}$ \\
\hline State & & & $\begin{array}{l}-0.150^{*} \\
(0.052)\end{array}$ & $\begin{array}{c}-0.554^{* *} \\
(0.235)\end{array}$ & $\begin{array}{c}-0.126^{* *} \\
(0.052)\end{array}$ & $\begin{array}{l}0.443^{*} \\
(0.141)\end{array}$ \\
\hline Local government & & & & & $\begin{array}{l}-0.115 \\
(0.119)\end{array}$ & $\begin{array}{c}0.325 \\
(0.334)\end{array}$ \\
\hline Civic organisation & & & $\begin{array}{l}-0.471^{*} \\
(0.114)\end{array}$ & $\begin{array}{l}-0.221 \\
(0.519)\end{array}$ & $\begin{array}{c}-0.384^{*} \\
(0.104)\end{array}$ & $\begin{array}{c}0.274 \\
(0.291)\end{array}$ \\
\hline Foreign & & & $\begin{array}{l}-0.182 \\
(0.113)\end{array}$ & $\begin{array}{l}-0.541 \\
(0.517)\end{array}$ & $\begin{array}{l}-0.087 \\
(0.080)\end{array}$ & $\begin{array}{c}0.351 \\
(0.225)\end{array}$ \\
\hline $\begin{array}{l}\text { Joint venture } \\
\text { (Domestic-foreign) }\end{array}$ & & & $\begin{array}{c}-0.185 * * \\
(0.070)\end{array}$ & $\begin{array}{c}0.208 \\
(0.313)\end{array}$ & $\begin{array}{l}-0.058 \\
(0.055)\end{array}$ & $\begin{array}{c}0.123 \\
(0.157)\end{array}$ \\
\hline \multicolumn{7}{|l|}{ Legal form: } \\
\hline Incorporated individual & & & $\begin{array}{c}0.267 * * * \\
(0.142)\end{array}$ & $\begin{array}{l}-0.116 \\
(0.650)\end{array}$ & $\begin{array}{c}0.104 \\
(0.135)\end{array}$ & $\begin{array}{c}-0.774 * * \\
(0.368)\end{array}$ \\
\hline Partnership & & & & & $\begin{array}{l}-0.091 \\
(0.148)\end{array}$ & $\begin{array}{l}-0.476 \\
(0.413)\end{array}$ \\
\hline Limited liability & & & $\begin{array}{l}0.363 * \\
(0.099)\end{array}$ & $\begin{array}{c}0.743 \\
(0.452)\end{array}$ & $\begin{array}{l}-0.024 \\
(0.128)\end{array}$ & $\begin{array}{r}-0.788 * * \\
(0.352)\end{array}$ \\
\hline
\end{tabular}

* Significant at $1 \%$.

** Signigicant at $5 \%$.

*** Significant at $10 \%$.

Note: The Constant term (base) refers to 'other' ownership and legal form. 
Table 3. (Continued)

\begin{tabular}{|c|c|c|c|c|c|c|}
\hline & \multicolumn{2}{|c|}{$1989-90$} & \multicolumn{2}{|c|}{ 1990-91 } & \multicolumn{2}{|c|}{ 1991-92 } \\
\hline & (1) & (2) & (1) & (2) & (1) & (2) \\
\hline Unequal partnership & & & & & $\begin{array}{l}-0.066 \\
(0.173)\end{array}$ & $\begin{array}{l}-0.580 \\
(0.481)\end{array}$ \\
\hline Joint venture & & & & & $\begin{array}{l}-0.088 \\
(0.193)\end{array}$ & $\begin{array}{l}-0.820 \\
(0.541)\end{array}$ \\
\hline Association & & & $\begin{array}{l}0.587^{*} \\
(0.125)\end{array}$ & $\begin{array}{c}0.280 \\
(0.573)\end{array}$ & $\begin{array}{l}-0.224 \\
(0.192)\end{array}$ & $\begin{array}{l}-0.540 \\
(0.540)\end{array}$ \\
\hline Joint stock company & & & $\begin{array}{l}0.364^{*} \\
(0.091)\end{array}$ & $\begin{array}{l}1.231^{*} \\
(0.414)\end{array}$ & $\begin{array}{c}0.011 \\
(0.125)\end{array}$ & $\begin{array}{l}-0.540 \\
(0.347)\end{array}$ \\
\hline $\begin{array}{l}\text { Agricultural co- } \\
\text { operative }\end{array}$ & & & & & $\begin{array}{c}0.008 \\
(0.248)\end{array}$ & $\begin{array}{c}0.433 \\
(0.698)\end{array}$ \\
\hline Co-operative & & & & & $\begin{array}{l}-0.092 \\
(0.205)\end{array}$ & $\begin{array}{l}-0.252 \\
(0.560)\end{array}$ \\
\hline $\begin{array}{l}\text { Agricultural co- } \\
\text { operative subsidiary }\end{array}$ & & & & & $\begin{array}{c}0.477 \\
(0.288)\end{array}$ & $\begin{array}{l}1.651^{* *} \\
(0.793)\end{array}$ \\
\hline Industrial co-operative & & & & & $\begin{array}{c}0.013 \\
(0.199)\end{array}$ & $\begin{array}{l}-0.198 \\
(0.540)\end{array}$ \\
\hline Other co-operative & & & & & $\begin{array}{c}0.054 \\
(0.216)\end{array}$ & $\begin{array}{c}0.147 \\
(0.591)\end{array}$ \\
\hline Multiparty joint venture & & & & & $\begin{array}{l}-0.050 \\
(0.279)\end{array}$ & $\begin{array}{c}-1.470 * * * \\
(0.784)\end{array}$ \\
\hline State enterprise & & & $\begin{array}{l}0.351^{*} \\
(0.091)\end{array}$ & $\begin{array}{l}1.115^{* *} \\
(0.414)\end{array}$ & $\begin{array}{l}-0.033 \\
(0.125)\end{array}$ & $\begin{array}{c}-0.606 * * * \\
(0.348)\end{array}$ \\
\hline $\begin{array}{l}\text { Other state } \\
\text { organisations }\end{array}$ & & & $\begin{array}{c}0.077 \\
(0.117)\end{array}$ & $\begin{array}{c}0.801 \\
(0.525)\end{array}$ & $\begin{array}{l}-0.126 \\
(0.142)\end{array}$ & $\begin{array}{c}-0.775^{* *} \\
(0.391)\end{array}$ \\
\hline Unknown & & & & & $\begin{array}{l}-0.123 \\
(0.169)\end{array}$ & $\begin{array}{l}-0.602 \\
(0.465)\end{array}$ \\
\hline $\begin{array}{l}\text { Domestic-foreign } \\
\text { partnership }\end{array}$ & & & & & $\begin{array}{l}-0.077 \\
(0.198)\end{array}$ & $\begin{array}{c}-1.403^{* *} \\
(0.545)\end{array}$ \\
\hline Military state enterprise & & & $\begin{array}{l}0.276^{* *} \\
(0.115)\end{array}$ & $\begin{array}{c}0.880 \\
(0.526)\end{array}$ & $\begin{array}{c}0.008 \\
(0.163)\end{array}$ & $\begin{array}{c}-0.874^{* *} \\
(0.453)\end{array}$ \\
\hline Municipal organisations & & & $\begin{array}{l}0.643^{*} \\
(0.146)\end{array}$ & $\begin{array}{c}0.659 \\
(0.669)\end{array}$ & $\begin{array}{c}0.066 \\
(0.265)\end{array}$ & $\begin{array}{l}-1.001 \\
(0.739)\end{array}$ \\
\hline Industry dummies & Yes & Yes & Yes & Yes & Yes & Yes \\
\hline Region dummies & Yes & Yes & Yes & Yes & Yes & Yes \\
\hline $\bar{R}^{2}$ & 0.99 & 0.84 & 0.99 & 0.84 & 0.97 & 0.79 \\
\hline $\mathbf{N}$ & 1,290 & 1,290 & 1,751 & 1,751 & 2,933 & 2,944 \\
\hline
\end{tabular}

* Significant at $1 \%$.

** Signigicant at 5\%.

*** Significant at $10 \%$.

Note: The Constant term (base) refers to 'other' ownership and legal form. 
As may be seen from the 1989-90 Column (1) in Table 3, the short-term elasticity of labour demand with respect to sales, given by the coefficient on $\ln Q_{\text {, was statistically }}$ significant, but small, at 0.1 in the pre-transition period. In the turbulent $1990-91$ period, this short-term elasticity remained low at 0.07 but, as transition unfolded, it rose to 0.35 , suggesting that firms started reacting to output changes by adjusting employment. It is worth noting that the corresponding static estimates of output elasticity, in Columns (2) of Table 3, are high and decreasing over time. These estimates are, of course, essentially cross-sectional ones, reflecting to a significant extent the fact that employment varies positively with output across firms.

The short-term employment elasticity with respect to the wage, given by the coefficient on $\ln W_{t}$, was -0.28 before the transition and turned to positive 0.25 in 1990 91 as both real wages and employment fell during the 'big bang' of 1991. In 1991-92 the elasticity became again negative at -0.19 . As in the case of sales, the statistically dominated static specifications in Columns (2) of Table 3 point to a high and, since 1990-91, decreasing elasticity of labour demand with respect to the wage.

While the mainstream view is that private firms hoard less labour than state-owned ones, the effect of ownership on employment in the Czechoslovak data is not uniform and clear-cut. In Table 3 we also present estimates of the effect of ownership and legal form. In particular, during the transition, Czechoslovak firms with given ownership could register under various (and changing) legal forms. We have, therefore, included types of ownership as well as the various legal forms as dummy variables in the regressions. In the dynamic specifications reported in Columns (1) of Table 3, the estimated coefficients on the ownership variables indicate that in 1990-91 and 1991-92 the state-owned enterprises reduced employment more significantly than private and foreign-owned firms. These findings may, of course, be consistent with the hypothesis that state-owned enterprises have been quite dynamic but had, and perhaps continue to have, more labour than the private and foreign-owned firms. The coefficients from the static specifications in Columns (2), reflecting to a large extent cross-sectional differences among firms, are consistent with this story. While the dummy variable on state ownership is negative and significant at -0.55 in the turbulent period of 1990-91, when one takes into account the effect of legal form, the differential between state and non-state firms basically disappears. In 1991-92, state-owned enterprises are, in fact, found to have a higher level of employment, ceteris paribus, than either private or foreign-owned firms. This suggests that as late as 1991-92 state-owned firms still had a larger stock of labour, ceteris paribus, than the other types of firm. The domestic-foreign joint ventures are an interesting case, showing a significant reduction in employment in 1990-91, and resembling the employment behaviour of private firms thereafter.

\subsubsection{The Polish estimates}

The Polish estimates in Table 4 are based on the large industrial dataset containing almost 5,000 firms. They show coefficient estimates on lagged employment of 1.00 in the 1988-89 period. Taken together with the other coefficients, this result indicates that the first difference specification characterizes well the pre-reform period. By 1989-90, as the 'big bang' started, the dynamic model dominates and the coefficient on lagged employment dips significantly below unity. Clearly more research in this area will be needed as data for additional years come on-stream.

The short-run sales elasticity of employment is estimated at 0.34 in 1988-89 and 0.25 in 1989-90. The two elasticities are not significantly different from one another and are similar to the corresponding elasticity of 0.35 found in Czechoslovakia during the transition (1991-92). Poland hence entered the transition with employment reacting to output changes more readily than it did in Czechoslovakia before and at the start of the 
transition, and it was only by 1991-92 that the Czech elasticity paralleled that of Poland in 1989-90. The corresponding static (cross-sectional) employment elasticity with respect to output stayed about constant at $0.81-0.83$ in the $1988-90$ period, displaying little of the decline observed in Czechoslovakia.

Table 4. IV estimates of employment equation for Polish firms, 1988-90

(Dependent variable is $\ln L_{i}$; values in parentheses are standard errors)

\begin{tabular}{|c|c|c|c|c|}
\hline & \multicolumn{2}{|c|}{$1988-89$} & \multicolumn{2}{|c|}{$1989-90$} \\
\hline & (1) & (2) & (1) & $(2)$ \\
\hline $\ln L_{t-1}$ & $\begin{array}{l}1.003 * \\
(0.027)\end{array}$ & & $\begin{array}{l}0.894^{*} \\
(0.026)\end{array}$ & \\
\hline $\ln Q_{1}$ & $\begin{array}{l}0.338^{*} \\
(0.064)\end{array}$ & $\begin{array}{l}0.833^{*} \\
(0.008)\end{array}$ & $\begin{array}{l}0.250^{*} \\
(0.072)\end{array}$ & $\begin{array}{l}0.814^{*} \\
(0.011)\end{array}$ \\
\hline $\ln Q_{1-1}$ & $\begin{array}{c}-0.339 * \\
(0.072)\end{array}$ & & $\begin{array}{c}-0.156^{* *} \\
(0.072)\end{array}$ & \\
\hline $\ln \mathbf{W}_{t}$ & $\begin{array}{c}-0.215^{* * * *} \\
(0.126)\end{array}$ & $\begin{array}{c}-0.703^{*} \\
(0.146)\end{array}$ & $\begin{array}{c}-0.413^{*} \\
(0.144)\end{array}$ & $\begin{array}{c}-0.999 * \\
(0.206)\end{array}$ \\
\hline $\ln \mathbf{W}_{t-1}$ & $\begin{array}{c}0.177 \\
(0.116)\end{array}$ & & $\begin{array}{l}0.409^{*} \\
(0.093)\end{array}$ & \\
\hline Industry dummies & Yes & Yes & Yes & Yes \\
\hline Region dummies & Yes & Yes & Yes & Yes \\
\hline Type dummies & Yes & Yes & Yes & Yes \\
\hline $\bar{R}^{2}$ & 0.98 & 0.83 & 0.98 & 0.85 \\
\hline $\mathbf{N}$ & 4,922 & 4,922 & 4,858 & 4,858 \\
\hline
\end{tabular}

* Significant at $1 \%$.

** Significant at $5 \%$.

*** Significant at $10 \%$.

As in the Czechoslovak data, the short-run wage elasticity of labour demand is negative, but it displays no switching of the sign and, in fact, rises significantly from -0.22 in 198889 to -0.41 in 1989-90. The Polish data thus indicate that the negative relationship was not reversed during the 'big bang' and, in fact, became stronger. The static model also produces negative and rising elasticities, with the values being higher than in the dynamic specifications.

The estimates of the employment equation for 161-163 Polish firms in 1992-93 are presented in Table 5. The dynamic specification in Column (1) generates a similar point estimate for lagged employment as did the 1989-90 data in Table 4. The estimates of shortrun output effect $(0.23)$ and wage effect $(-0.29)$ also are very similar to those found in the large sample for 1989-90. These estimates, together with those on lagged output and wages, thus suggest that dynamic adjustment in the labour market remained similar between 1990 and 1993. 
Table 5. OLS estimates of employment equation (1') for Polish firms, 1992-93

(Dependent variable is $\ln L_{1} ;$ values in parentheses are standard errors)

\begin{tabular}{|c|c|c|}
\hline & (1) & (2) \\
\hline $\ln L_{1-3}$ & $\begin{array}{l}0.878^{*} \\
(0.037)\end{array}$ & \\
\hline $\ln \mathbf{Q}$ & $\begin{array}{l}0.226^{*} \\
(0.048)\end{array}$ & $\begin{array}{l}0.722^{*} \\
(0.038)\end{array}$ \\
\hline $\ln Q_{1-1}$ & $\begin{array}{c}-0.123 * * \\
(0.057)\end{array}$ & \\
\hline $\ln W_{t}$ & $\begin{array}{c}-0.291^{*} \\
(0.068)\end{array}$ & $\begin{array}{c}-0.714^{*} \\
(0.149)\end{array}$ \\
\hline $\ln W_{1-1}$ & $\begin{array}{l}0.397^{*} \\
(0.082)\end{array}$ & \\
\hline (Liq. assets/current liab.), & $\begin{array}{c}0.036 * * * \\
(0.020)\end{array}$ & $\begin{array}{l}-0.010 \\
(0.051)\end{array}$ \\
\hline (Liq. assets/current liab. $)_{t-1}$ & $\begin{array}{c}-0.036^{* * *} \\
(0.019)\end{array}$ & $\begin{array}{l}-0.017 \\
(0.049)\end{array}$ \\
\hline$\%$ Equipment $>15$ yrs old & $\begin{array}{c}0.0001 \\
(0.0010)\end{array}$ & $\begin{array}{l}0.00047 \\
(0.0012)\end{array}$ \\
\hline$\% \mathrm{Q}$ based on foreign design & $\begin{array}{c}0.0011^{* *} \\
(0.0005)\end{array}$ & $\begin{array}{l}0.005^{*} \\
(0.001)\end{array}$ \\
\hline \% Capacity utilization & $\begin{array}{l}0.00034 \\
(0.0007)\end{array}$ & $\begin{array}{c}-0.0012 \\
(0.0019)\end{array}$ \\
\hline Perceived market share & $\begin{array}{c}0.00017 \\
(0.00041)\end{array}$ & $\begin{array}{c}0.0004 \\
(0.0011)\end{array}$ \\
\hline$\%$ of labour unionized & $\begin{array}{c}0.0007 \\
(0.0007)\end{array}$ & $\begin{array}{c}0.0058^{*} \\
(0.0018)\end{array}$ \\
\hline Emerging private firm & $\begin{array}{c}0.042 \\
(0.062)\end{array}$ & $\begin{array}{c}-0.694^{*} \\
(0.141)\end{array}$ \\
\hline Privatized firm & $\begin{array}{c}-0.129^{*} \\
(0.039)\end{array}$ & $\begin{array}{c}-0.205^{* *} \\
(0.098)\end{array}$ \\
\hline Commercialized SOE & $\begin{array}{r}-0.056 \\
(0.035)\end{array}$ & $\begin{array}{l}-0.038 \\
(0.093)\end{array}$ \\
\hline Industry dummies & Yes & Yes \\
\hline Region dummies & Yes & Yes \\
\hline $\bar{R}^{2}$ & 0.988 & 0.914 \\
\hline $\mathbf{N}$ & 161 & 163 \\
\hline
\end{tabular}

* Significant at $1 \% . \quad * * \quad$ Significant at $5 \% . \quad * * * \quad$ Significant at $10 \%$.

Note: The Constant term refers to traditional state-owned enterprises. 
Table 6. IV estimates of wage equation for Czechoslovak firms, 1989-92

(Dependent variable is in $L_{t}$; values in parentheses are standard errors)

\begin{tabular}{|c|c|c|c|c|c|c|}
\hline & \multicolumn{2}{|c|}{ 1989-90 } & \multicolumn{2}{|c|}{ 1990-91 } & \multicolumn{2}{|c|}{ 1991-92 } \\
\hline & (1) & (2) & (1) & $(2)$ & (1) & (2) \\
\hline $\ln \mathbf{W}_{1-1}$ & $\begin{array}{l}0.912^{*} \\
(0.029)\end{array}$ & & $\begin{array}{l}0.851^{*} \\
(0.042)\end{array}$ & & $\begin{array}{l}0.778^{*} \\
(0.044)\end{array}$ & \\
\hline $\ln (Q / L)$ & $\begin{array}{l}0.067^{*} \\
(0.012)\end{array}$ & $\begin{array}{l}0.093^{*} \\
(0.011)\end{array}$ & $\begin{array}{l}0.102^{*} \\
(0.009)\end{array}$ & $\begin{array}{l}0.147^{*} \\
(0.010)\end{array}$ & $\begin{array}{l}0.150^{*} \\
(0.027)\end{array}$ & $\begin{array}{l}0.115^{*} \\
(0.011)\end{array}$ \\
\hline $\ln (Q / L)_{t-1}$ & $\begin{array}{l}-0.031^{* *} \\
(0.012)\end{array}$ & & $\begin{array}{c}-0.032 * * \\
(0.012)\end{array}$ & & $\begin{array}{c}-0.100 * \\
(0.028)\end{array}$ & \\
\hline \multicolumn{7}{|l|}{ Ownership: } \\
\hline Private & & & $\begin{array}{l}0.107 * * \\
(0.047)\end{array}$ & $\begin{array}{c}0.075 \\
(0.072)\end{array}$ & $\begin{array}{l}-0.036 \\
(0.035)\end{array}$ & $\begin{array}{c}0.007 \\
(0.042)\end{array}$ \\
\hline Co-operative & & & $\begin{array}{c}0.113 \\
(0.108)\end{array}$ & $\begin{array}{c}0.172 \\
(0.165)\end{array}$ & $\begin{array}{c}0.083 \\
(0.107)\end{array}$ & $\begin{array}{c}-0.289^{* *} \\
(0.129)\end{array}$ \\
\hline State & & & $\begin{array}{l}-0.011 \\
(0.039)\end{array}$ & $\begin{array}{l}-0.070 \\
(0.060)\end{array}$ & $\begin{array}{c}-0.066^{* * *} \\
(0.033)\end{array}$ & $\begin{array}{l}-0.025 \\
(0.041)\end{array}$ \\
\hline Local government & & & & & $\begin{array}{c}0.019 \\
(0.081)\end{array}$ & $\begin{array}{l}-0.143 \\
(0.100)\end{array}$ \\
\hline Civic organisation & & & $\begin{array}{c}0.088 \\
(0.086)\end{array}$ & $\begin{array}{c}0.065 \\
(0.130)\end{array}$ & $\begin{array}{l}0.219 * \\
(0.071)\end{array}$ & $\begin{array}{l}-0.125 \\
(0.087)\end{array}$ \\
\hline Foreign & & & $\begin{array}{l}-0.116 \\
(0.086)\end{array}$ & $\begin{array}{l}-0.114 \\
(0.130)\end{array}$ & $\begin{array}{l}-0.053 \\
(0.055)\end{array}$ & $\begin{array}{c}0.049 \\
(0.067)\end{array}$ \\
\hline $\begin{array}{l}\text { Joint venture } \\
\text { (domestic-foreign) }\end{array}$ & & & $\begin{array}{l}0.120^{* *} \\
(0.051)\end{array}$ & $\begin{array}{c}0.115 \\
(0.078)\end{array}$ & $\begin{array}{c}0.039 \\
(0.038)\end{array}$ & $\begin{array}{l}0.101^{* *} \\
(0.047)\end{array}$ \\
\hline Legal form dummies & No & No & Yes & Yes & Yes & Yes \\
\hline Industry dummies & Yes & Yes & Yes & Yes & Yes & Yes \\
\hline Region dummies & Yes & Yes & Yes & Yes & Yes & Yes \\
\hline $\bar{R}^{2}$ & 0.87 & 0.87 & 0.77 & 0.49 & 0.62 & 0.39 \\
\hline $\mathbf{N}$ & 1,290 & 1,290 & 1,751 & 1,751 & 2,933 & 2,933 \\
\hline
\end{tabular}

* Significant at $1 \%$.

** Significant at $5 \%$.

*** Significant at $10 \%$.

Note: The Constant term (base) refers to 'other' ownership and legal form. 
Table 7. IV estimates of wage equation for Polish firms, 1988-90

(Dependent variable is $\ln W_{1}$; values in parentheses are standard errors)

\begin{tabular}{lcccc}
\hline & \multicolumn{2}{c}{$1988-1989$} & \multicolumn{2}{c}{$1989-1990$} \\
& $(1)$ & $(2)$ & $(1)$ & $(2)$ \\
\hline $\ln \mathbf{W}_{t \cdot 1}$ & $0.826^{*}$ & & $0.581^{*}$ & \\
& $(0.058)$ & & $(0.060)$ & \\
$\ln (\mathbf{Q} / \mathbf{L})_{1}$ & 0.128 & $0.200^{*}$ & $0.297^{*}$ & $0.191^{*}$ \\
& $(0.115)$ & $(0.014)$ & $(0.043)$ & $(0.010)$ \\
$\ln (\mathbf{Q} / \mathrm{L})_{t \cdot 1}$ & -0.013 & & $-0.254^{*}$ & \\
& $(0.120)$ & & $(0.054)$ & \\
Type dummies & Yes & Yes & Yes & Yes \\
Industry dummies & Yes & Yes & Yes & Yes \\
Region dummies & Yes & Yes & Yes & Yes \\
$\overline{\boldsymbol{R}}^{2}$ & 0.45 & 0.327 & 0.627 & 0.49 \\
$\mathbf{N}$ & 4,922 & 4,922 & 4,858 & 4,858 \\
\hline
\end{tabular}

* Significant at $1 \%$.

** Significant at $5 \%$.

$* * *$ Significant at $10 \%$.

The 1992-93 survey also permits us to explore the employment effect of a number of structural features of these firms. The quick ratio (liquid assets/current liabilities), proxying the lack of financial distress of the firm, has a positive short-term effect on employment. The vintage of capital, proxied by the percentage of equipment that is reported to be more than 15 years old, does not appear to affect employment. Firms with a greater share of output based on foreign design tend to employ more workers, while capacity utilization and perceived market share are unrelated to employment. Unionization does not affect employment in the dynamic framework, although in the static (cross-sectional) model one finds that more unionized firms tend to have more employees, ceteris paribus. Similarly, emerging private and privatized firms have significantly fewer employees than traditional state-owned firms in the static estimates. However, when the previous year's employment level is taken into account through the dynamic specification, the effect persists only in the case of privatized firms. Commercialization does not have a strong negative effect on employment in any specification.

\subsection{Wages}

Estimates of the wage equations based on the three datasets are reported in Tables 6-8, respectively. Our empirical strategy is analogous to that used in estimating the employment equations-dynamic and static models are estimated on short (two-year) panels.

The estimates based on the 1989-92 Czechoslovak data indicate that the effect of the previous year's wage on current wage was diminishing steadily from 0.91 in 1989-90 to 0.78 in 1991-92. The initial inertia in wage-setting was thus diminishing over time. 
Table 8. OLS estimates of wage equation for Polish firms, 1992-93

(Dependent variable is In $W_{1}$; values in parentheses are standard errors)

\begin{tabular}{|c|c|c|}
\hline & (1) & $(2)$ \\
\hline $\ln \mathbf{W}_{t-1}$ & $\begin{array}{l}0.687^{*} \\
(0.097)\end{array}$ & \\
\hline $\ln (Q / L)$ & $\begin{array}{l}0.326^{*} \\
(0.058)\end{array}$ & $\begin{array}{l}0.237^{*} \\
(0.040)\end{array}$ \\
\hline $\ln (Q / L)_{1-1}$ & $\begin{array}{c}-0.269 * \\
(0.069)\end{array}$ & \\
\hline In (liq. assets/ current liab.), & $\begin{array}{c}0.003 \\
(0.026)\end{array}$ & $\begin{array}{c}0.012 \\
(0.030)\end{array}$ \\
\hline In (liq. assets/ current liab.) ${ }_{t-1}$ & $\begin{array}{c}0.035 \\
(0.024)\end{array}$ & $\begin{array}{c}0.058^{* *} \\
(0.028)\end{array}$ \\
\hline \% Sales exported to CMEA & $\begin{array}{c}0.005^{* *} \\
(0.002)\end{array}$ & $\begin{array}{l}0.004^{* *} \\
(0.002)\end{array}$ \\
\hline \% Sales exported to non-CMEA, & $\begin{array}{c}0.0003 \\
(0.0008)\end{array}$ & $\begin{array}{c}0.000 \\
(0.001)\end{array}$ \\
\hline$\%$ Sales to government & $\begin{array}{c}0.001 \\
(0.001)\end{array}$ & $\begin{array}{c}0.002 \\
(0.002)\end{array}$ \\
\hline Perceived market share & $\begin{array}{c}0.0007 \\
(0.0005)\end{array}$ & $\begin{array}{c}0.0006 \\
(0.0006)\end{array}$ \\
\hline \% Labour unionized & $\begin{array}{c}0.0012 \\
(0.0009)\end{array}$ & $\begin{array}{c}0.001 \\
(0.001)\end{array}$ \\
\hline$\%$ Debt to firms overdue $>1$ year & $\begin{array}{l}-0.0016 \\
(0.0011)\end{array}$ & $\begin{array}{c}-0.001 \\
(0.001)\end{array}$ \\
\hline$\%$ Debt to banks overdue $>1$ year & $\begin{array}{c}-0.0002 \\
(0.0011)\end{array}$ & $\begin{array}{c}0.0004 \\
(0.0013)\end{array}$ \\
\hline$\%$ Debt to government overdue $>1$ year & $\begin{array}{c}-0.0002 \\
(0.0009)\end{array}$ & $\begin{array}{l}-0.001 \\
(0.001)\end{array}$ \\
\hline$\%$ of receivables overdue $>1$ year & $\begin{array}{c}0.0003 \\
(0.0009)\end{array}$ & $\begin{array}{l}-0.001 \\
(0.001)\end{array}$ \\
\hline Emerging private firm & $\begin{array}{c}0.021 \\
(0.082)\end{array}$ & $\begin{array}{l}-0.037 \\
(0.096)\end{array}$ \\
\hline Privatized firm & $\begin{array}{l}-0.052 \\
(0.051)\end{array}$ & $\begin{array}{c}0.031 \\
(0.059)\end{array}$ \\
\hline Commercialized SOE & $\begin{array}{l}-0.009 \\
(0.045)\end{array}$ & $\begin{array}{l}-0.042 \\
(0.053)\end{array}$ \\
\hline Industry dummies & Yes & Yes \\
\hline Region dummies & Yes & Yes \\
\hline$\overline{\boldsymbol{R}}^{2}$ & 0.639 & 0.483 \\
\hline$\underline{\mathbf{N}}$ & 157 & 159 \\
\hline
\end{tabular}

* Significant at $1 \%$.

** Significant at 5\%.

*** Significant at $10 \%$. 
The short-term wage effect of sales per employee, proxying the firm's ability to pay, is found to be positive and increasing over time from 0.07 in 1989-90 to 0.15 in 199192. The wage-setting process thus increasingly reflected firm-specific ability to pay rather than general labour market conditions.

While raw data show that, on average, private firms pay less and foreign firms pay more than others, the multiple regression framework indicates that this pattern does not hold very clearly, once we control for other variables such as sales per employee. Indeed, private firms and domestic-foreign joint ventures appear to have increased wages relative to others in 1990-91, while state-owned firms reduced wages in 1991-92. The static 1991-92 estimates indicate that co-operatives pay significantly less and joint ventures more than all other firms.

The 1988-90 Polish estimates reported in Table 7 imply a relatively low and declining level of inertia in the wage-setting process, with the coefficient on lagged wage in the dynamic model dropping from 0.83 in 1988-89 to 0.58 in 1989-90. The estimated short-run elasticity of output per employee on wages is found to be positive and rising from a statistically insignificant 0.13 in $1988-89$ to significant 0.30 in $1989-90$. The effect of a firm's ability to pay on wages was thus increasing over time and became more important in Poland than in Czechoslovakia during the transition. The Polish effect is found to be significantly positive and stable at $0.19-0.20$ in the static framework.

Estimates based on the 1992-93 Polish survey data, reported in Table 8, also generate a relatively low coefficient $(0.69)$ on lagged wage. Moreover, the 0.32 short-run elasticity of sales per employee (firm's ability to pay) on wages is very similar to the 0.30 point estimate found in the large sample in 1989-90 in Table 7 . The static elasticity estimate of 0.24 is also quite similar to the 0.19 estimate found in the large sample. Like the employment equation estimates, the wage equation estimates thus suggest that the dynamics remained relatively unchanged between 1989-90 and 1992-93.

Wages are also found to be unrelated to financial distress of the firm, but they are positively related to the percentage of sales exported to the former CMEA countries. The latter finding suggests that the former CMEA market is less competitive, allowing firms to generate greater surplus and hence pay higher wages. Perceived market share, degree of unionization of the firm's labour force, long-term indebtedness or receivables are all found to be unrelated to wages. Similarly, ownership and commercialization are found to have no effect on wages, once productivity, industry and region have been controlled for.

\section{Concluding observations}

This paper seeks to illustrate restructuring behaviour in firms in the early years of transition by using panel data methods to explore wage and employment adjustment between pairs of years at the enterprise level. The datasets being studied represent virtually all industrial firms in Czechoslovakia and Poland respectively in the relevant periods.

The estimated equations highlight some important aspects of enterprise behaviour at the start of the transformation process. Firstly, we confirm that Polish firms were already more responsive to external and market pressures than their Czechoslovak counterparts in 1990, in the sense that inertia in employment and wage-setting was typically lower, and market or firm specific factors were already significant and displaying higher elasticities in the Polish sample. However, it is striking that almost immediately after the Czechoslovak 'big bang' in 1991, the relevant elasticities there started to increase and often reached the levels attained by Poland a few years previously. The Polish elasticities 
continued to rise in the same period, though at a less dramatic rate.

This suggests there may be a common pattern to these elasticities through the transition process, as firms find themselves for the first time facing hard budget constraints and changing external market conditions. In the period of central planning, decisions on employment and wages were explained primarily by the previous year's experience but, as market pressures begin to bite, employment adjustments become more closely associated with sales, while wages tend to be increased more in line with the firm's ability to pay. Poland had already embarked on this path before the reforms of 1990, while the remnants of central planning were only finally abolished in Czechoslovakia at the start of 1991, which explains the different pattern of the estimated parameters. It is particularly interesting to note that by 1992 wage cost factors were beginning to play a significant role in employment decisions in Czechoslovak firms, with a negative significant coefficient on wages in the labour demand equation. Wage costs played a persistently more significant role in the more decentralized Polish economy, even at the start of transition.

The estimates also shed some light on the vexed question of ownership effects on employment and wages (see also Commander and Coricelli, 1994). The key finding is that, while there may be some impact from private or foreign owners on employment, one can find no comparable evidence in the wage equations once we control for differences in productivity. In Czechoslovakia, the equations show that state-owned firms reduce employment more than private or foreign-owned ones. We interpret this to imply that there was considerably more restructuring in state-owned firms, perhaps as a consequence of hard budget constraints (see Estrin, Gelb and Singh, 1995). However, state-owned firms are also found to have more over-manning than private companies, and many therefore have more of an employment restructuring problem to solve. These findings are consistent with the results from the small Polish sample as well. However, while the raw data suggest that, on average, foreign firms in Czechoslovakia paid more and private firms less, no clear pattern holds in the multiple regression framework. We find no significant ownership effects in the Polish wage equations.

\section{Endnotes}

1. In undertaking the research for this paper, Saul Estrin and Jan Svejnar were in part supported by a World Bank research grant on Enterprises in Transition. The authors would like to thank Lubomir Lizal and Lina Takla for valuable computer assistance.

2. University of Michigan, William Davidson Institute, $9^{\text {th }}$ Floor, 701 Tappan Street, Ann Arbor, Michigan 48109, USA.

3. Growth is now once again well established in most countries of Central Europe though not for the most part in the economies of the former Soviet Union (see EBRD Transition Report, 1995, 1996).

4. Real producer wages are defined as nominal wages deflated by the producer price index, while real consumer wages refer to nominal wages deflated by the consumer price index. Real wages have since risen.

5. In the case of the former Soviet Union, one observes low unemployment rates which are attributable primarily to the continuation of soft budget policies. These policies have presumably allowed firms to continue hoarding labour and thus prevented the rise of unemployment as in other transitional economies (see, e.g., 
Commander, 1994). Unemployment has now begun to fall in much of Central Europe in parallel with the strong growth performance, but it remains uncomfortably high.

6. The 200 firm sample is therefore not representative and one must be careful in using it to make inferences about the performance of Polish industrial firms in general. As Prasnikar, Svejnar, Mihaljek and Prasnikar (1994) have shown on Yugoslav data, non-random samples can produce misleading results in this area.

7. Using Czech and Slovak household expenditure data, Garner, Lubyova and Terrell (1995) also find an increase in the coefficient of variation for blue and white collar workers' incomes between 1989 and 1992.

8. See Lizal, Singer and Svejnar (1995) for an analysis of the spin-offs.

9. The summary statistics for the 1992-93 Polish survey of 200 firms are reported in Belka et. al. (1994).

10. The survey unfortunately does not contain exogenous series that could be successfully used as valid instruments in IV estimation.

\section{References}

Belka, M., S. Estrin, M. Schaffer, and I. Singh (1994), 'The Provision of Social Benefits in State-Owned, Privatized and Private Firms in Poland', LSE, Centre for Economic Performance, Discussion Paper, No.317.

Boycko, M., A. Shleifer and R. Vishny (1995), Privatizing Russia, Cambridge, Mass.: MIT Press.

Carlin, W. (1994), 'Privatization and De-industrialization in East Germany', In: S. Estrin, ed., Privatization in Central and Eastern Europe, London: Longman.

Commander, S. (1993), 'Unemployment in Eastern Europe: Social Disease or Economic Necessity?', Transition, 4(9), December.

Commander S. and F. Coricelli, eds., (1995), Unemployment, Restructuring, and the Labor Market in Eastern Europe and Russia, Washington D.C.: The World Bank.

Dyba, K. and J. Svejnar (1995), 'An Overview of Recent Economic Developments in the Czech Republic', In: Svejnar J., ed., The Czech Republic and Economic Transition in Eastern Europe, New York: Academic Press.

EBRD, Transition Reports, 1995, 1996.

Estrin, S., ed. (1994), Privatization in Central and Eastern Europe, London: Longman.

Estrin, S., A. Gelb and I. J Singh (1995), 'Shocks and Adjustment by Firms in Transition', Journal of Comparative Economics, Vol.21(2), pp.131-53.

Estrin, S. and J. Svejnar (1993), 'Wage Determination in Labor-Managed Firms under Market-Oriented Reforms: Estimates of Static and Dynamic Models', Journal of Comparative Economics, Vol. 17(3), pp.687-700.

Garner, T., M. Lubyova, and K. Terrell (1995), 'Changes in Expenditure and Income Inequality in the Czech and Slovak Republic, 1989 vs. 1992', In: Svejnar J., ed., The Czech Republic and Economic Transition in Eastern Europe, New York: Academic Press.

Hamermesh, D. (1986), 'The Demand for Labour in the Long Run', In: Ashenfelter, O.C. and R. Layard, eds., Handbook of Labor Economics, Vol.1, Amsterdam: North Holland, pp.429-71.

Hendry D. F. and G. Mizon (1978), 'Serial Correlation as a Convenient Simplification. 
Not a Nuisance', Economic Journal, 88(351), pp.549-63.

Lizal, L., M. Singer and J. Svejnar (1995), 'Manager Interests, Breakups and Performance of State Enterprises in Transition', In: Svejnar J., ed., The Czech Republic and Economic Transition in Eastern Europe, New York: Academic Press.

Nickell, S. J. (1986), 'Dynamic Models of Labour Demand', In: Ashenfelter, O.C. and R. Layard, eds., Handbook of Labour Economics, Vol.1, Amsterdam: North Holland, pp.473-522.

Prasnikar, J., J. Svejnar, D. Mihaljek and V. Prasnikar. (1994), 'Behaviour of Participatory Firms in Yugoslavia: Lessons for Transforming Economies', Review of Economics and Statistics, 76(4), pp.728-41.

Svejnar, J., ed. (1995), The Czech Republic and Economic Transition in Eastern Europe, New York: Academic Press. 